\title{
Portale społecznościowe - wpływ na dzieci i młodzież
}

\begin{abstract}
Social networking - impact on children and adolescents

The ubiquitous contemporary Internet creates unlimited opportunities to use social networking sites that bring opportunities and benefits to children and young people.

In this article, the essence and concept of social networking sites have been characterized and what functions they fulfill. The most popular contemporary social media sites have been listed and described, most of which are used by children and youth - Facebook, Nasza Klasa and Instagram. With the development of mobile devices, children have the possibility of unlimited use of portals that give them great opportunities and opportunities, which is also shown in the article. The fact remains that if something is so popular and widely available, it carries a lot of threats with which the young generation has contact, due to careless and unskilful use in everyday life.
\end{abstract}

Key words: social networking site, Facebook, Instagram, Nasza Klasa

\section{Wstęp}

Człowiek jest z natury istotą społeczną, dlatego dąży do tworzenia więzi z innymi ludźmi. Obecnie Internet jest powszechnym narzędziem umożliwiającym zawieranie takich relacji, dlatego też jest on najczęściej wykorzystywany przez młodzież.

Nowe media bezsprzecznie przyczyniły się do przełomu w zakresie komunikacji medialnej. Dzieci i młodzież najczęściej komunikują się między sobą poprzez portale społecznościowe, takie jak Facebook, NK czy Instagram. Portale 
te umożliwiają zawieranie nowych znajomości, podtrzymywanie tych, które już mamy, a także umożliwiają udostępnianie własnych zdjęć do użytku publicznego, dzięki czemu mogą zobaczyć je nasi znajomi.

Popularny slogan mówi: „jak Cię nie ma na Facebooku, to nie istniejesz”. Coraz bardziej staje się on prawdziwy, ponieważ jest to jeden z najpopularniejszych serwisów internetowych na świecie, który każdego dnia odwiedzają miliony osób.

Portale społecznościowe umożliwiają nie tylko komunikację, ale również szereg innych funkcji, które sprawiają, że tak chętnie z nich korzystamy. Mimo świadomości zagrożeń ich popularność ciągle rośnie.

\section{Charakterystyka portali społecznościowych}

Terminy „serwis społecznościowy” oraz „portal społecznościowy” stosuje się zamiennie. Rozumie się je jako serwis internetowy, który istnieje w oparciu o zgromadzoną wokół niego społeczność. Sposób ich funkcjonowania oraz treści w nich zawarte są tworzone lub współtworzone głównie przez użytkowników mających swoje spersonalizowane profile. Społeczności te skupiają się wokół podobnych zainteresowań, nacji, zawodów, religii etc. i tworzą grupy osób znających się także ze świata realnego bądź znających się tylko poprzez Internet ${ }^{1}$.

Portal społecznościowy stwarza możliwość szeroko rozumianej interakcji pomiędzy użytkownikami - komunikację, wymianę tekstów, zdjęć czy też innych materiałów. Przykładami serwisów społecznościowych są: Wikipedia.org, Facebook.com, NaszaKlasa.pl, Youtube.com, Flickr.com, MySpace.com, Grono.net, Fotografia.interklasa. $\mathrm{pl}^{2}$.

Serwis społecznościowy, bez względu na swój charakter, powinien oferować użytkownikom pewne charakterystyczne dla nich funkcje i aktywności - przede wszystkim:

- możliwość stworzenia własnego profilu,

- możliwość uzupełniania informacji profilowych,

- możliwość dodawania zdjęć,

- możliwość wchodzenia w interakcje z innymi użytkownikami,

- możliwość dołączenia do różnego rodzaju grup,

- możliwość decydowania o poziomie prywatności konta³.

${ }_{1}$ Serwis społecznościowy lub portal społecznościowy, http://www.i-slownik.pl/2559,serwis-spolecznosciowy-lub-portal-spolecznosciowy/ [dostęp: 25.01.2018].

2 T. Goban-Klas, Kompetencja medialna kluczem do sukcesu młodego pokolenia w społeczeństwie wiedzy, Polski Portal Edukacyjny Interkl@sa 2010, s. 33.

${ }_{3}^{3}$ M. Drabek, M. Klimowicz, Serwisy społecznościowe i oferowane przez nie możliwości monitorowania losów zawodowych absolwentów szkół wyższych, Warszawa-Wrocław 2013, s. 50. 
Portale społecznościowe mogą być nakierowane na tworzenie i udostępnianie informacji (Wikipedia), danego rodzaju materiałów (np. zdjęć - serwis Flickr), ale miewają też charakter ogólny, który można określić jako towarzyski (służą rozrywce oraz utrzymywaniu relacji ze znajomymi, np. Nasza Klasa czy Facebook)․

\section{Facebook, Nasza Klasa, Instagram}

Obecnie istnieje duża różnorodność serwisów społecznościowych, których użytkownikami możemy stać się w dowolnej chwili, i tylko od nas zależy, który z nich wybierzemy. Każdy z portali ma za zadanie umożliwić kontakt pomiędzy użytkownikami, z tym że komunikacja odbywa się w różny sposób i poprzez odmienne narzędzia, które udostępniają do dyspozycji poszczególne serwisy.

Facebook jest serwisem, który łączy ludzi z całego świata. Samo korzystanie z Facebooka należy potraktować jako wspólne doświadczenie kulturowe dla wszystkich mieszkańców powstałej w ten sposób globalnej wioski. Choć punktem wyjścia Facebooka był skromny projekt 19-letniego studenta, obecnie portal jest technologicznym gigantem, który ma ogromny i bezprecedensowy wpływ na wszystkie aspekty współczesnego życia, zarówno prywatnego, jak i publicznego ${ }^{5}$. Został stworzony w 2004 r. przez studenta Uniwersytetu Harvarda - Marka Zuckerberga - jako zamknięty serwis społecznościowy skierowany do amerykańskich studentów, a następnie również do uczniów szkół średnich. W 2006 r. został udostępniony dla wszystkich użytkowników z całego świata, którzy posiadają aktywny adres mailowy oraz mają więcej niż 13 lat, stając się wkrótce najważniejszym serwisem społecznościowym w skali globalnej i jednocześnie tworząc punkt odniesienia dla wielu innych tego typu przedsięwzięć. Polska wersja językowa serwisu została aktywowana w maju $2008 \mathrm{r}^{6}$

Prywatni użytkownicy mają zazwyczaj oznaczone profile (lecz niekoniecznie) prawdziwym imieniem i nazwiskiem, zawierające zdjęcie profilowe, zdjęcie tła, a także dodatkowe informacje o sobie, które są podzielone na kategorie:

- informacje podstawowe (data urodzenia, znajomość języków obcych, poglądy religijne oraz polityczne),

- zdobyte wykształcenie oraz informacje o pracy (ukończone szkoły i uczelnie wyższe, przeważnie bez podziału na klasy i profile w ramach kierunków kształcenia) - zazwyczaj podawana jest bieżąca lub ostatnia afiliacja zawodowa i edukacyjna,

\footnotetext{
4 T. Goban-Klas, dz. cyt., s. 33.

${ }^{5}$ D. Kirkpatrick, Efekt Facebooka, Warszawa 2001, s. 22-23.

${ }^{6}$ M. Drabek, dz. cyt., s. 11.
} 
- miejsce zamieszkania (aktualne i tzw. miasto rodzinne),

- informacje kontaktowe (numer telefonu, adres mailowy),

- rodzina (członkowie rodziny mający facebookowe profile i zaakceptowani w ramach serwisu jako rodzina),

- informacja o znajomych (liczba znajomych oraz linki do ich profili) ${ }^{7}$.

Facebook jest obecnie dla wielu polskich nastolatków głównym miejscem cyfrowej aktywności. W lipcu 2014 r. w raporcie sporządzonym przez zespół Sotrendera wykazano, że w grupie wiekowej 13-18 lat użytkownikami Facebooka w Polsce było ponad dwa i pół miliona osób (2 680 000), przy łącznej liczbie aktywnych użytkowników przekraczającej 12 milionów osób ${ }^{8}$.

Komunikacja za pośrednictwem Facebooka ma znacząco odmienny charakter niż ta przebiegająca "twarzą w twarz”. Różnice te wynikają z odmiennej formy wypowiedzi, ponieważ na Facebooku kontaktujemy się wyłącznie na czacie w formie tekstu pisanego, $\mathrm{z}$ reguły synchronicznego, chociaż możliwe jest użycie trybu asynchronicznego, w którym informacja adresowana do znajomego będzie odczytana przez niego w innym czasie, niż jest stworzona. Komunikacja asynchroniczna jest opcją bardzo praktyczną, gdyż pozwala na pozostawienie wiadomości, ale używając jej, nadawca nigdy nie ma pewności, czy i kiedy adresat odczytał wiadomość. Tekstowy sposób komunikacji jest szczególnie przyjazny dla osób młodych, przyzwyczajonych do szybkiego, skrótowego porozumiewania się tekstowego za pomocą urządzeń mobilnych, ale może być uciążliwy dla osób dojrzałych i starszych. Ci ostatni nie mają z reguły biegłości w pisaniu na klawiaturze, nie są także przyzwyczajeni do specyficznie krótkiego wypowiadania się czy korzystania z emotikonów. Komunikacja na czacie różni się także od komunikacji telefonicznej, która pozwala na szersze, narracyjne wypowiedzi. Tekstowa forma wypowiedzi na Facebooku tak znacząco odbiega od komunikacji w świecie realnym, że przekłada się to, przynajmniej w początkowej fazie korzystania z portalu, na zmniejszoną częstość kontaktów przez czat i mniejszą wagę spraw omawianych za jego pośrednictwem. Facebook nie ma możliwości bezpośredniej komunikacji głosowej ani wizualnej, którą posiada np. Skype. To w ogromnej mierze ogranicza komunikację i zubaża ją, nie dając możliwości przesłania sygnałów niewerbalnych (mowa ciała, intonacja głosu, barwa głosu, specyficzny sposób mówienia). Komunikacja tekstowa na czacie jest bardzo ograniczona, pozbawiona subtelności, z trudem posługuje metaforą. Sieć jest innym niż realne środowiskiem funkcjonowania człowieka, w którym komunikacja zapośredniczona komputerowo różni się od komunikacji w świecie rzeczywistym. Ma to wpływ na zmianę zachowań użytkowników sieci,

\footnotetext{
7 Tamże, s. 12.

${ }^{8}$ G. Penkowska, Fenomen Facebooka. Społeczne konteksty edukacji, Gdańsk 2014, s. 9.
} 
a zjawisko to zaobserwowane przez psychologów Internetu nazywane jest rozhamowaniem zachowania w Internecie 9

Facebook z całą pewnością zmienił obraz współczesnej komunikacji. Wykazuje on wszystkie cechy, które przypisywane są kategorii nowych mediów, a są nimi: cyfrowość, interaktywność, hipertekstualność, usieciowienie oraz wirtualność ${ }^{10}$.

Z kolei użytkownicy serwisu Nasza Klasa od początku jego istnienia mogą założyć w nim osobisty profil, umieścić awatar, zapisać się do istniejących szkoły/ klasy/kierunku bądź założyć własną listę, wysłać innemu użytkownikowi prywatną wiadomość, zostawić wpis na jego profilu, a także publikować albumy ze zdjęciami. Serwis w dalszej kolejności wzbogacił się także o kolejne funkcjonalności, z których najważniejsze to:

- „śledzik” - funkcja umożliwiająca śledzenie aktywności innych użytkowników portalu,

- komunikator NK - wzorowany na komunikatorze Facebooka oraz funkcjonalnościach Gadu-Gadu,

- aplikacje z grami - także wzorowane na aplikacjach Facebooka ${ }^{11}$.

Ponadto na portalu możliwe jest odpłatne wysyłanie wirtualnych prezentów i dedykowanie piosenek. Użytkownik może kontrolować, kto i w jakim stopniu ma dostęp do jego profilu ${ }^{12}$. Za pośrednictwem portalu można dzielić się swoimi codziennymi doświadczeniami, zdjęciami czy też ciekawostkami, można budować sieci znajomych, utrzymywać stałe kontakty z ludźmi z całego świata, ale i odnawiać kontakty z przyjaciółmi z przeszłości ${ }^{13}$.

Z kolei Instagram to fotograficzny serwis społecznościowy, stworzony przez Kevina Systrom’a i Mika Krieger’a w USA w 2010 r. Facebook zakupił go w 2012 r. Aktualnie Instagram ma ponad $400 \mathrm{mln}$ aktywnych użytkowników. Umożliwia dzielenie się zdjęciami i krótkimi filmami video (do 15 sekund). Obrazy mogą być powiązane z lokalizacją. W aplikacji można zmieniać kilka atrybutów zdjęć, np.: jasność, kontrast, cienie i perspektywę, można też dodawać specjalne filtry. Cechą wyróżniającą Instagram od innych podobnych serwisów umożliwiających wymianę zdjęć jest fakt, że aplikacja nadaje im kwadratowy kształt. Większość aparatów tworzy bowiem obrazy w standardowej proporcji 3:4. Profil użytkownika można uzupełnić o informacje biograficzne i połączyć konto z kontem na Facebooku

\footnotetext{
9 A.N. Joinson, Przyczyny i skutki rozhamowanego zachowania w Internecie, [w:] Internet a psychologia. Możliwości i zagrożenia, red. W. Paluchowski, Warszawa 2009, s. 135.

${ }^{10}$ J. Nowak, Aktywność obywateli online. Teoria a praktyka, Lublin 2011, s. 16-18.

11 M. Drabek, dz. cyt., s. 22.

${ }_{12}$ M. Małecka, B. Małecki, Analiza rozwoju portali społecznościowych w Internecie, Polska Agencja Rozwoju Przedsiębiorczości, Warszawa 2008, s. 6.

${ }_{13}$ J. Lizut, Zagrożenia cyberprzestrzeni. Kompleksowy program dla pracowników służb społecznych, Warszawa 2014, s. 268.
} 
oraz Twitterze. Użytkownicy Instagrama mogą obserwować zdjęcia zamieszczane przez innych oraz komentować zdjęcie dodawane przez inne osoby ${ }^{14}$. Umieszczane w serwisie fotografie mają udowodnić, że autor zdjęcia był w jakimś miejscu czy też spotkał się z konkretną osobą. Należy jednak zaznaczyć, że oprócz indywidualnych motywacji niektóre fotografie umieszczane na Instagramie przez znanych użytkowników zawierają głębsze przesłanie ${ }^{15}$.

Instagram rozwija się bardzo dynamicznie, korzystają już z niego ponad $3 \mathrm{mi}-$ liony osób. Tylko w ciągu 2014 r. liczba użytkowników podwoiła się. Większość z tych osób stanowiły kobiety oraz osoby powyżej 18 . roku życia ${ }^{16}$.

\section{Szanse płynące z portali społecznościowych}

Portale społecznościowe od kilku lat podbijają rynek internetowy w Polsce. Młodzi ludzie coraz częściej żartem podkreślają, że jeśli „nie ma cię na Facebooku, to nie istniejesz". Wraz z rozwojem mobilnych urządzeń dzieci mają możliwość nieograniczonego korzystania z portali - w domu, w szkole czy gdziekolwiek przebywają.

Do najważniejszych korzyści osobistych płynących z dostępu do serwisów społecznościowych zalicza się:

- zwiększenie skuteczności i możliwości wpływania na innych użytkowników,

- autoprezentację i promocję swojego profilu osobistego,

- subiektywne poczucie szczęścia i satysfakcji,

- poprawę samopoczucia i zdrowia (według statystyk wśród osób mających rozwinięte więzi społeczne ryzyko problemów ze zdrowiem jest kilkakrotnie mniejsze $)^{17}$.

Wielu nie dostrzega walorów edukacyjnych portali społecznościowych, a tymczasem badania wskazują na ich duży potencjał. Młodzież chętnie spędza tam swój wolny czas, a także coraz częściej w dowolnym miejscu i w dowolnej chwili loguje się na ulubionym serwisie za pomocą urządzeń mobilnych. Wykorzystanie naturalnego środowiska ucznia może przynieść szereg korzyści. A. Keen w swojej książce Jak Internet niszczy kulturę napisał, że należy szukać sposobu na wykorzystanie

${ }^{14}$ J. Paliszkiewicz, Rola mediów społecznościowych w innowacyjnym kształceniu, [w:] Innowacje w zarzadzaniu i inżynierii produkcji, t. II, red. R. Knosala, Opole 2016, s. 916.

15 A. Bąk, Serwisy społecznościowe - efekt Facebooka i nie tylko, „Media i Społeczeństwo” 2016, nr 6, s. 142.

${ }_{16}$ M. Kostrzewska, Dlaczego ptaszek nie wszędzie ćwierka tak samo głośno? Czyli social media po polsku, [w:] Social media 2010-2015-2020, „Nowy Marketing”, październik 2015, s. 26.

17 T. Goban-Klas, dz. cyt., s. 34. 
tego, co najlepsze w cyfrowej przyszłości, ale należy przy tym pamiętać, by nie niszczyć dawnych instytucji ${ }^{18}$.

Obecnie praktycznie całe klasy mają konta na Facebooku, w związku z tym część nauczycieli moderuje grupy uczniowskie, tworząc tak zwane tajne grupy zamknięte, widoczne jedynie dla zapisanych członków. Przesyłają informacje, zadania domowe, zagadnienia, zasoby edukacyjne (np. w formie linków), rozwiązują problemy wychowawcze i konflikty grupowe ${ }^{19}$. Facebook i podobne portale mogą być wykorzystane do prowadzenia różnorodnych projektów dydaktycznych, np. śledzenie wątków i grup o zainteresowaniach związanych $\mathrm{z}$ treścią przedmiotu lub kursu, dzielenie się opiniami na temat przeczytanych lektur, obejrzanych filmów, udostępnianie oraz publikowanie opracowań i prac przygotowanych przez uczniów, granie w tematyczne gry online, które wymagają umiejętności i wiedzy uzyskiwanej w trakcie zajęć, organizowanie konkursów, głosowań i burz mózgów, nawiązywanie kontaktu z ekspertami z danej dziedziny, politykami, innymi grupami szkoleniowymi i nauczycielami czy uzyskiwanie informacji i partycypowanie w konkursach związanych $\mathrm{z}$ nauczanym przedmiotem ${ }^{20}$.

Facebook to marka sama w sobie, której w dzisiejszej dobie nie trzeba nikomu przedstawiać. Ten portal społecznościowy daje swoim użytkownikom ogrom możliwości, począwszy od utrzymywania kontaktów ze znajomymi, bez względu na miejsce zamieszkania, poprzez możliwość dzielenia się ze znajomymi zdjęciami, przemyśleniami, wiadomościami, muzyką. Umożliwia też tworzenie sieci i grup oraz korzystanie z aplikacji będących własnością Facebooka. Dzieci i młodzież korzystają z nieograniczonego dostępu do Internetu w szkole, kafejce internetowej, bibliotece czy też w zaciszu własnego domu. Pozwala im to na dzielenie się doświadczeniami oraz utrzymywanie zażyłych kontaktów ze swoimi rówieśnikami. Jest to przywilej, o jakim poprzednie pokolenia mogły jedynie pomarzyć ${ }^{21}$.

Facebook łączy wirtualne społeczności cyfrowych tubylców, do których każdy ma dostęp i jednocześnie każdy może uczestniczyć w ich tworzeniu. W różny, właściwy sobie sposób może zaznaczyć swój ślad, podsunąć jakąś myśl, którą można poddać dyskusji. Może podzielić się ciekawym zasobem, filmem, muzyką, obrazem, przekonaniami, sądami, opiniami. Ma to wpływ na kreowanie osobistych preferencji, kompetencji i upodobań. Niematerialne nośniki informacji, kultury, sztuki oddziałują na osoby tak, jak te ze świata materialnego. Treść, a nie forma przekazu czy jej materialny atrybut, jest istotą zrozumienia. Wirtualna

18 A. Keen, Kult amatora. Jak Internet niszczy kulture, Warszawa 2007, s. 170.

${ }_{19}$ G. Penkowska, dz. cyt., s. 19-20.

${ }^{20}$ M. Dziubińska, Facebook, Twitter, Skype - moi nauczyciele, Ministerstwo Edukacji Narodowej 2014, s. 2.

${ }^{21}$ G. Penkowska, dz. cyt., s. 62. 
rzeczywistość to świat symboli zakodowanych. Wiele rzeczy, tak jak i w życiu realnym, dzieje się zupełnie przypadkowo, przeszukując sieć, natrafimy niekiedy na prawdziwe arcydzieło ${ }^{22}$.

Kulturotwórcze funkcje Facebooka są realizowane na różne sposoby. Jedna z ważniejszych, funkcja informacyjna, czyli pobieranie i udostępnianie informacji, jest typową aktywnością łączącą sferę prywatną i publiczną na portalach społecznościowych. W upowszechnianiu treści obie sfery łączą się nieustannie, gdyż użytkownicy o statusie „znajomi” wymieniają się informacjami bieżącymi z różnych dziedzin życia, czasem bardzo prywatnymi, a czasem dotyczącymi szkoły, uczelni, urzędów, kin itp. Uczniowie przekazują sobie informacje odnoszące się do terminów czy organizacji egzaminów i imprez, umawiają się na spotkania, omawiają sprawy bieżące. Ze względu na mniej formalny sposób komunikacji także w dyskusjach wkraczają na teren prywatny, czasem nawet plotkują. Levinson twierdzi, że znajomi z Facebooka są najlepszym źródłem wiedzy, i to wiedzy wymienianej w czasie rzeczywistym ${ }^{23}$.

Dziś brak konta na Facebooku wiąże się z wykluczeniem z dyskursu publicznego. Choć różne mogą być tego przyczyny - własna decyzja, brak dostępu do Internetu, cenzura lub inne - nieodmiennie oznacza to ograniczony dostęp do wielu informacji czy wydarzeń. Nastolatki organizują 18. urodziny, wykorzystując dostępne na Facebooku narzędzie do tworzenia tak zwanych wydarzeń. Ogłaszają publicznie datę i miejsce wydarzenia, a następnie zapraszają znajomych, którzy mogą również publicznie zadeklarować udział. Firmy organizują specjalne promocje tylko dla tych facebookowiczów, którzy regularnie śledzą ich fanpage. A osoby publiczne zarówno ze świata rozrywki, sportu, jak i polityki wykorzystują serwis do wzmacniania własnej popularności ${ }^{24}$.

\section{Zagrożenia}

Mimo dużej popularności portali społecznościowych oraz szans, jakie stwarzają one dla dzieci i młodzieży, należy też pamiętać o szeregu zagrożeń. Należą do nich m.in.: brak prywatności, coraz mniejsze znaczenie komunikacji bezpośredniej, uzależnienie od świata wirtualnego, nieodpowiednie wykorzystanie przez inne osoby naszych danych umieszczonych na profilu.

Głównymi i najniebezpieczniejszymi zagrożeniami związanymi z korzystaniem $\mathrm{z}$ serwisów społecznościowych są między innymi zjawiska obsesyjnego

\footnotetext{
22 Tamże, s. 18.

${ }^{23}$ P. Levinson, Nowe media, Warszawa 2010, s. 192.

${ }^{24}$ G. Penkowska, dz. cyt., s. 79.
} 
przywiązania do serwisów społecznościowych, w tym natrętnego sprawdzania swojego konta, zagrożenie kradzieżą dóbr użytkowników, takich jak dane osobowe lub publikowane materiały prywatne (zdjęcia, dokumenty, artykuły etc.), nieraz natrętne, agresywne lub złośliwe zachowanie innych użytkowników serwisów ${ }^{25}$.

Na serwisach społecznościowych toczy się także swoisty wyścig o przyjaciół. Przykładowo w serwisie Nasza Klasa użytkownicy mają możliwości pokazywania swoich przyjaciół innym. Są też tacy, którzy mają ich nawet kilka tysięcy. Przyjaciół kolekcjonuje się jak gadżety, a im ich więcej na swoim profilu, tym lepiej. Okazuje się, że na serwisach aukcyjnych pojawiają się ogłoszenia, gdzie ktoś oferuje bycie lojalnym przyjacielem na Naszej Klasie lub przyjazne wpisy. Nie mają tutaj znaczenia prawdziwe więzy przyjaźni, liczy się tylko liczba kontaktów. Nieznane właścicielowi danego profilu osoby w zamian za pieniądze odgrywają role wiernych przyjaciół z przeszłości.

Użytkownicy mają szeroki wachlarz wirtualnych prezentów, które można zakupić za określoną kwotę i przesłać swoim znajomym, m.in. sztabkę złota, koronę, truskawkę, cukierki, podkowę, szampana, serce, tort, kwiaty, ale także, np. kubeł zimnej wody. Prezenty mają swoje stopnie prywatności. W publicznych serwisach nadawcę prezentu może widzieć każdy użytkownik serwisu, z kolei w prywatnych nadawcę zna tylko odbiorca, a użytkownicy widzą jedynie prezent. Życie na pokaz - analogicznie jak w świecie realnym - kwitnie w internetowych serwisach społecznościowych. Związki międzyludzkie na Naszej Klasie przypominają jedynie wielką wystawę, targ próżności, np. popatrz, jak wielu mam znajomych, zobacz, jaką sympatią innych się cieszę. Pokazywanie siebie i swojej pozycji społecznej znajduje swój wyraz także w zdjęciach, jakie użytkownicy Naszej Klasy zamieszczają na portalu. W serwisie tym można chwalić się wszystkim, a szczególnie osiągniętym bogactwem czy zdobytymi znajomościami ${ }^{26}$. Chęć posiadania jak największej liczby znajomych wywołana jest presją rówieśników oraz potrzebą udowodnienia pozostałym, jak popularnym i lubianym się jest. W efekcie niejednokrotnie dzieci i młodzież dodają do grona swoich znajomych osoby, których nie znają w realnym świecie, równocześnie narażając się na czyhające z tego tytułu zagrożenia ${ }^{27}$.

Bardzo istotnym zagrożeniem dla dzieci w serwisach jest przejmowanie ich profili i szarganie reputacji w wyniku kradzieży tożsamości. Haker, który zdobędzie dane potrzebne do zalogowania do profilu ofiary, może je wykorzystać do przejęcia tego profilu, użycia loginu i hasła do logowania do innych usług, a także

25 T. Goban-Klas, dz. cyt., s. 34.

${ }^{26}$ M. Szpunar, Prawdziwych przyjaciół poznaje się $w$ Internecie. Serwisy społecznościowe $i$ ich użytkownicy, [w:] Media w wychowaniu chrześcijańskim, red. D. Bis, A. Rynio, Lublin 2010, s. 508.

${ }^{27}$ G. Penkowska, dz. cyt., s. 68. 
do szargania opinii przez opublikowanie w profilu ofiary kompromitujących informacji. Szczególnie dokuczliwym zagrożeniem jest wykorzystywana niekiedy możliwość zwyczajnego znęcania się poprzez wysyłanie obraźliwych wiadomości, szantaż oraz nękanie użytkowników ${ }^{28}$.

Podobnie jak przemoc fizyczna, przemoc stosowana w Internecie może pozostawić trwały ślad w psychice dziecka i mieć w przyszłości negatywny wpływ na jego pewność siebie, umiejętność podejmowania decyzji czy też nawiązywania relacji międzyludzkich. Przemoc stosowana wobec młodego człowieka może skutkować w dorosłym życiu tym, że osoba taka nie będzie potrafiła zaufać otaczającym ją ludziom. Po szczególnie traumatycznych przeżyciach nie będzie umiała znaleźć bezpiecznego dla siebie miejsca, swojego życiowego azylu ${ }^{29}$.

\section{Zakończenie}

Portale społecznościowe cieszą się ogromną popularnością tak na całym świecie, jak i w Polsce. Niosą ze sobą zarówno szanse, jak i zagrożenia, dlatego trzeba z nich rozsądnie korzystać. Mają obecnie duży wkład w edukację, a ich potencjał mogą wykorzystać jedynie kreatywni nauczyciele.

Normalną sytuacją jest, iż styczność z komputerem rozpoczyna się już w wieku przedszkolnym i nie mamy na to żadnego wpływu, ale ważne jest, aby odpowiednio chronić dzieci i zawsze tłumaczyć im zasady funkcjonowania Internetu oraz portali społecznościowych na tyle, na ile pozwala wiek rozwojowy dziecka. Jest to ważne zadanie dla rodziców, opiekunów i nauczycieli.

${ }^{28}$ J. Gruber, Zagrożenia dla informacji udostępnianych na portalach społecznościowych, „Zeszyty Naukowe Politechniki Śląskiej” 2012, s. 356.

29 Tamże, s. 64. 


\section{BIBLIOGRAFIA}

Bąk A., Serwisy społecznościowe - efekt Facebooka i nie tylko, „Media i społeczeństwo" 2016, nr 6.

Drabek M., Klimowicz M., Serwisy społecznościowe i oferowane przez nie możliwości monitorowania losów zawodowych absolwentów szkół wyższych, Warszawa-Wrocław 2013.

Dziubińska M., Facebook, Twitter, Skype - moi nauczyciele, Ministerstwo Edukacji Narodowej 2014.

Goban-Klas T., Kompetencja medialna kluczem do sukcesu młodego pokolenia w społeczeństwie wiedzy, Polski Portal Edukacyjny Interkl@sa 2010.

Gruber J., Zagrożenia dla informacji udostępnianych na portalach społecznościowych, „Zeszyty Naukowe Politechniki Śląskiej” 2012.

Joinson A.N., Przyczyny i skutki rozhamowanego zachowania w Internecie, [w:] Internet a psychologia. Możliwości i zagrożenia, red. W. Paluchowski, Warszawa 2009.

Keen A., Kult amatora. Jak Internet niszczy kulture, Warszawa 2007.

Kirkpatrick D., Efekt Facebooka, Warszawa 2001.

Kostrzewska M., Dlaczego ptaszek nie wszędzie ćwierka tak samo głośno? Czyli social media po polsku, [w:] Social media 2010-2015-2020, „Nowy Marketing", październik 2015.

Levinson P., Nowe nowe media, Warszawa 2010.

Lizut J., Zagrożenia cyberprzestrzeni. Kompleksowy program dla pracowników stużb społecznych, Warszawa 2014.

Małecka M., Małecki B., Analiza rozwoju portali społecznościowych w Internecie, Warszawa 2008.

Melosik Z., Kultura popularna i tożsamość młodzieży. W niewoli władzy i wolności, Kraków 2013.

Nowak J., Aktywność obywateli online. Teoria a praktyka, Lublin 2011.

Paliszkiewicz J., Rola mediów społecznościowych w innowacyjnym kształceniu, [w:] Innowacje $w$ zarzadzaniu i inżynierii produkcji, t. II, red. R. Knosala, Opole 2016.

Penkowska G., Fenomen Facebooka. Społeczne konteksty edukacji, Gdańsk 2014.

Serwis społecznościowy lub portal społecznościowy, http://www.i-slownik.pl/2559, serwis-spolecznosciowy-lub-portal-spolecznosciowy/ [dostęp: 25.01. 2018].

Szpunar M., Prawdziwych przyjaciół poznaje się w Internecie. Serwisy społecznościowe i ich użytkownicy, [w:] Media w wychowaniu chrześcijańskim, red. D. Bis, A. Rynio, Lublin 2010.

Szymański G., Snapchat jako innowacyjna aplikacja marketingu mobilnego, „Zeszyty Naukowe Politechniki Częstochowskiej. Zarządzanie” 2016, nr 22. 